\title{
WOMEn As MARTYRs: MASS SUICIDES AT THOA KHALSA DURING THE PARTITION OF INDia
}

\author{
ARUNIMA DEY \\ Universidad de Salamanca \\ arunima011@gmail.com
}

Received: 18-03-2015

Accepted: 06-06-2015

\begin{abstract}
The paper is an attempt at understanding the mass suicides committed by women during the communal riots instigated by the partition of the Indian subcontinent. Firstly, the position and the role assigned to women are investigated by applying Giorgio Agamben's concept of bios and zoē within a gendered perspective; this forms the introductory theoretical framework of the topic. The core part of the paper concentrates on one significant event which took place in the village of Thoa Khalsa, Rawalpindi district (now in Pakistan) in March 1947, where ninety women took their own lives as a desperate attempt to avoid rape, abduction and religious conversion, thereby averting the ruination of their community's honour. Bhisham Sahni's depiction of the episode in his semi-autobiographic novel, Tamas, along with testimonies and print media sources, allows for exploration of the notion of national and religious honour and, more importantly, whether the suicides were a decision made by a person actively responsible for her own fate or rather someone passively succumbing to the patriarchal expectations of the state and community.
\end{abstract}

KEYWORDS: Indian Partition; communal violence; suicide; Indian women; patriarchy; honour; Thoa Khalsa; Bhisham Sahni.

\section{RESUMEN Mujeres mártires: suicidios en masa en Thoa Khalsa durante la Partición de India}

El presente ensayo pretende comprender los suicidios en masa que tuvieron lugar durante los enfrentamientos populares en la Partición del Subcontinente indio. En primer lugar, se pretende analizar la posición y el rol que les fueron asignados a las mujeres. Para ello, se seguirán los principios teóricos de bios y zoē formulados por Giorgio Agamben incluyendo una perspectiva de género. En segundo lugar, el artículo se centra en un suceso en particular que tuvo lugar en el pueblo de Thoa Khalsa (distrito de Rawalpindi, ahora en Pakistán) durante marzo de 1947 y en el que se suicidaron noventa mujeres con el objetivo de evitar violaciones, secuestros y la conversión religiosa (sucesos que mancharían el honor de la 
comunidad a la que pertenecían). El estudio de la novela de Bhisman Sahni, Tamas, que ilustra el evento histórico con fragmentos semi-autobiográficos, servirá, junto el análisis de recortes de prensa de la época, para investigar los conceptos de nación y honor religioso y (aspecto más importante) plantear la interrogación sobre si estos suicidios fueron una decisión de gente activamente responsable por su propio destino, o más bien de gente que sucumbía pasivamente a las expectativas patriarcales del estado y de su comunidad.

PALABRAS CLAVE: Partición de India; violencia popular; suicidio; mujer en India; patriarcado; honor; Thoa Khalsa; Bhisman Sahni

"The right of sovereignty was the right to take life or let live. And then this new right is established: the right to make live and let die.”

- Michel Foucault in Society Must Be Defended (Foucault, 2003: 241)

In the context of the late 1940s Indian subcontinent, with new borders etched out with religious violence, the above quotation from Michel Foucault may be be interpreted through several lenses. One of the more obvious interpretations would be how the sovereign nations of India and the newly-formed Pakistan decided to methodically divide the citizens on the basis of their religion. The Partition was brought into effect by the sovereign (but one must note that it was the people), who urged by fear and instinct of self-preservation coupled with hatred, made the decision regarding who gets to live and who dies, and this decision was solely dependent on whether one is rightfully geographically located as per one's religious beliefs. The extent to which the sovereign was responsible in advocating the communal massacres still remains a matter of great debate and dispute among scholars, historians, sociologists and political analysts, and it is beyond the scope of this paper to engage in the same. The attempt here is to investigate the underlying gender politics; casting 'man' in the role of the sovereign, and with the same implications, woman in the role of the people.

In mid-twentieth century India, women were circumscribed within the private borders of home. Their lack of any political or economic engagement translated into an insulated existence from the outside world vis-à-vis the government. The sovereign affected the man; the subsequent effect on the woman took the form of what may be defined as a chain reaction. The household for the woman, isolated from the outside world, becomes a microcosm of the nation where the 
man is the ruler/sovereign. The familial government of patriarchy which runs at home fundamentally controls her life. The most widely used word for husband in Hindi, a language overwhelmingly spoken in Northern India, is pati; the word etymologically signifies owner or master. Another word, swami, equates the master-slave distinction between a husband and a wife in yet more glaring clarity; swami implies a godlike lord.

Over time immemorial, it has been said that 'man' is a social animal; he is social because he is a part of the political and economic system. The man purveys his religion, his caste and his class. But, where does one situate the woman? The woman becomes an object for the purpose of defining the man, rather than holding an identity of her own. Hence, at a (supposed) time of need to assert one's religious identity, for instance the Hindu-Muslim riots during the Partition of India (1947) the woman-object became woman-object-signifier. Her status did not change, however, her body, her gender and its control by the (active) subject-man emerged as a trope for assertion of religious supremacy.

The societal construct with respect to gender roles permits certain comparisons with ancient Greek society, which segregated its people into citizens and non-citizens. A citizen had rights to participate in the polis and the juridical order while slaves and women were considered noncitizens. Giorgio Agamben, in the introduction to his book Homo Sacer, attempts to distinguish between two forms of life: "zoe, which expressed the simple fact of living common to all living beings (animals, men, or gods), and bios, which indicated the form or way of living proper to an individual or a group" (Agamben, 1998: 1). Agamben's zoē is that which merely exists, as opposed to bios which lives. To live is to be actively social (or socially active?), via the two modes of participation in what may be defined as social activities and assertion of one's social identity through the means of one's nationality, religion and other social pointers. In the 1940s Indian subcontinent, these two modes find their fruition in the social conduct of men, and therefore, they effectively represent the bios. The women, however, limited to the territorial boundaries of home, are enhancers and markers of the social standings of the men to whom they belong as wives, daughters or mothers. Isolated from the polis, they exist as $z o \bar{e}$ for the purpose of enabling men to live as bios. 
In light of the aforementioned comments, the paper seeks to explore the gruesome episode of mass suicide of women during the religious riots as narrated in Bhisham Sahni's novel of Partition Tamas. ${ }^{1}$ Sahni's fictional retelling of the Partition was first published in Hindi in 1974, and was subsequently translated into English by the author and published in that version in 2001. The story draws from Sahni's own experience of the Partition as well as other actual events of the time, including the story of a small town in Rawalpindi district (now in Pakistan) called Thoa Khalsa, where ninety women jumped into a well in order to protect their 'honour' when the village got ambushed by a Muslim mob. For the women and the community, suicide was the obvious alternative as opposed to abduction, religious conversion and rape by the Other; the case is that of $z o \bar{e}$ sacrificed to safeguard the dignity of the bios. The incident took place in midMarch and an article on the event appeared on $12^{\text {th }}$ April 1947 in an English-language newspaper, The Statesman:

The story of 90 women of the little village of Thoa Khalsa, Rawalpindi district... who drowned themselves by jumping into a well during the recent disturbances has stirred the imagination of the people of the Punjab. They revived the Rajput tradition of self-immolation when their menfolk were no longer able to defend them. They also followed Mr. Gandhi's advice to Indian women that in certain circumstances, even suicide was morally preferable to submission. (as cited in Butalia, 1998: 196)

The tone of the article is at best, ambiguous. The incident has been said to have "stirred the imagination of the people". Does it imply a reaction satiated with grief and horror or mere amazement and praise for the 'martyrs'? It reflects strongly on the role imposed on women by society; the article simply states that the reason for the suicide was that "their menfolk were no longer able to defend them." Not only does it blatantly imply that women are incapable of any form of self-defence, further emphasizing their dependency on men: the act itself is taken to be transpicuous, seen an easy corollary to the archaic and patriarchal Rajput customs (of the westerly princely state of Rajasthan). Heroism for women therefore can find articulation only in self-annihilation. The use of words such as "revived" and "tradition" indicates a sense of patency, the patriarchal state lending a sense of legitimacy to the act.

\footnotetext{
'The word 'Tamas' in Hindi has several negative meanings such as inertia, destruction, ignorance etc. In the context of the novel, it is usually translated as 'darkness', signifying the corruption of humanist values evident in the merciless killings and plunderings which occurred during the communal riots at the time of the Partition of India.
} 
Apart from the newspaper article, many flyers appeared in the following months commemorating the incident as a matter of immense pride for the Sikh community where the self-sacrifice of the women was portrayed as a mark of Sikh courage and valour. Historian Gyanendra Pandey, in Remembering Partition: Violence, Nationalism and History in India, reproduces the content of one among many leaflets circulated among the Sikh community in the month of July 1947:

- THE DEATH-DEFYING SISTERS OF RAWALPINDI -THE PRIDE OF POTHOHAR THOSE BRAVE DAUGHTERS OF GURU ARJAN - WHO PREFERRED VOLUNTARY DEATH - SELF-INFLICTED OR AT THE HANDS OF THEIR DEAR ONES TO AN IGNOBLE LIFE. THEY ARE PHYSICALLY GONE. THEIR SPIRIT IS AN UNDYING FORCE. (as cited in Pandey, 2001: 86)

Women who during their lives are methodically demarcated to the category of sub-human creatures are now suddenly memorialized as "an undying force". Oscillating between an object and a role model imbued with noteworthy qualities, depending on the need of the hour, the society assigns the relevant part to women as it sees befitting. The sentence that proudly states that the women "preferred voluntary death" must be contested; to prefer may not necessarily entail want and voluntary does not entail desirable. Furthermore, the insistence of the society to view the deaths as preferred and voluntary takes us back to the comparison of women with zoë; they are denied the power to make a choice and are hegemonized in order to demonstrate the unsaid, yet nonetheless evident laws of the community as being their own decision. The deaths at Thoa Khalsa cannot be seen as voluntary suicides, but rather, only as community-orchestrated murder. The women's active participation in their deaths does not denote their agreement based upon an individual judgement, but is rather, a consequence of what they believed to be their duty to society.

In the novel, with the onset of communal violence, Sahni traces the fate of a Sikh family; its members located in different villages. At Khanpur, Haram Singh and his wife Banto, the only Sikh family in an otherwise Muslim village, flee in order to save their lives while the Muslim mob loots and burns down their house and tea-shop. Their son, Iqbal Singh, who lives in another predominantly Muslim village, tries to escape but is caught by the marauders, humiliated and forced to convert to Islam in order to live. Meanwhile, in the village of Sayedpur, which is said to be home to equal numbers of Sikh and Muslim citizens, the battle rages on but with the arrival 
of more Muslim attackers, the daughter, Jasbir, along with several other Sikh women, jump to their deaths into the town well.

Sahni's third-person perceptive of the 'well episode' adopts a quality of detachment rather than an emotional retelling of the incident. It appears to be sudden and unprecedented, and amidst the communal hatred and violence, discomfitingly takes on the appearance of being logical. Sahni's use of this technique is deliberate to further bring out the macabre quality of the incident:

Just at that time a group of women, emerged in the row from the gurudwara. ${ }^{2}$ At their head was Jasbir Kaur, her eyes half-open, her face flushed. Almost all women had taken their dupattas off their heads and tied them round their waists. They were all bare-footed, their faces too flushed. As though under a spell, they came out of the gurudwara. (Sahni, 2001:292)

It is of interest to note that a dupatta is a long scarf worn by Indian women, regardless of their religion. The scarf essentially means a 'lajja vastra', which translates to 'cloth of modesty'. It is used to cover the head and hangs around the shoulders covering the bosom. A covered head is a sign of submission and reverence, and therefore most married women and adolescent girls are obliged to cover their heads with a dupatta in the company of men and elders. A woman with an uncovered head is considered shameless and a disgrace to her father's and husband's family. The society does not permit the woman to exercise control over her own body, which can be seen as another example of the bios regulating the zoë's body. Sahni writes: "women had taken their dupattas off their heads and tied them round their waists." This is a very crucial gesture as the purpose of the dupatta is transformed from a 'cloth of modesty' to a cummerbund, to signify action or a stance of fight. In popular Indian culture, the gesture of tying the dupatta around the waist is symbolic of a determined woman who is prepared for a task ahead or/and ready to plunge into a difficult situation. However, in the novel, this gesture is neatly undercut by Sahni when he writes that the women seemed to be "under a spell". This spell is, to borrow a phrase from Louis Althusser, the spell of the Ideological State Apparatus. Althusser explains:

Ideological State Apparatuses function massively and predominantly by ideology, but they also function secondarily by repression, even if ultimately, but only ultimately, this is very attenuated and concealed, even symbolic. (There is no such thing as a purely ideological apparatus.) Thus Schools and Churches use suitable methods of punishment, expulsion, selection, etc., to 'discipline' not only their shepherds, but also their flocks. The same is true of

\footnotetext{
${ }^{2}$ Sikh place of worship, the word literally means 'the doorway to God/guru'.
} 
the Family.... The same is true of the cultural IS Apparatus (censorship, among other things), etc. (Althusser, 1971: 98)

Henceforth, the unwavering assertion that the deaths were a supposedly collective decision of the women is a thinly veiled attempt to mask the dominant ideology of the masculine state at its effective worst. The state, therefore, not just simply controls the body but also the minds of the women. The women, are clearly "under the spell" of the patriarchal state, which ensures that their psyche and mindset are deeply ingrained with the idea that their community's honour is dependent on their sexual purity and social code of conduct. The patriarchal hegemony attained through indoctrination of state-approved ideologies leads to the women adhering to selfannihilation, which gains the illusive quality of an act undertaken as entirely one's own decision.

Sahni strategically narrates the entire episode within three pages. It happens all too suddenly but one cannot overlook the dark shadow of the inevitable that accompanies it:

The throng of women headed towards the well located at the foot of the slope... They were running fast towards it, as though under a spell. None knew why and wherefore they were heading towards it. Under the translucent light of the moon it appeared as though fairies were flying down to the well. (Sahni, 2001: 292; emphasis added)

Almost as a refrain, Sahni repeats that the women appeared to be "under a spell." The dichotomy of the situation is constantly reaffirmed: the women appear to be in control of what they are doing and yet the suggesting undertone is that of being hypnotized, rendering their 'voluntary' act as mute. Sahni refers to them as "fairies", reinforcing how, as noted earlier, the woman as a person, ceases to exist; no longer a passive object, she has now metamorphosed into a fantastical creature. But, one must keep in mind that in Indian folklore, fairies, though usually portrayed as beautiful and with mystical powers, are subordinate to stronger masculine powers such as a powerful sage or a druid-like figure. If we understand the folklore against the backdrop of communal violence, the fairies may well be seen as a euphemism for the zoë, put under a spell to do the bidding of the master-sage sovereign.

Partha Chatterjee, in his essay "Colonialism, Nationalism, and Colonized Women: The Contest in India" states: "The new patriarchy advocated by nationalism conferred upon women the honor of a new social responsibility; and by associating the task of female emancipation with the historical goal of sovereign nationhood, bound them to a new, and yet entirely legitimate, subordination" (Chatterjee, 1989: 629). Chatterjee's 'new patriarchy' is one which emerges with 
the creation of new borders, and female emancipation only finds its fruition in death, or to use the state-preferred term, martyrdom. During a time marked with violence of ethnic cleansing, war-cries became an essential element of initializing an attack against the religious Other, and taking the respective gods' names became a perverse way to legitimize the killings and lootings. However, in the novel, Jasbir Kaur, the first woman to succumb to her fate, "raised no slogan, nor did she call anyone's name, she only uttered Wahe Guru and took the jump” (Sahni, 2001: 293). Wahe Guru in Sikhism is a term signifying the Supreme Lord: the phrase uttered is therefore a call to God. Unlike the men, Jasbir does not jump into the well with the Sikh jaikara ${ }^{3}$ or a call to arms; she is denied that authority as her act of self-sacrifice is ironically the result of passive succumbing to a state-sanctified ideology that calls for women's unquestioned acceptance of their community-validated emancipatory death.

Sahni closes the episode by marking clear demarcations, using a cacophony of voices: "The air was filled with the heart-rending cries of women and children coming from inside the well and were mingled with the loud shouts of "Allah-o-Akbar'4 and 'Sat Sri Akal" ${ }^{5}$ " (Sahni, 2001: 293294). As the war between the men rages on, both the Muslim and Sikh shouts of triumph are undercut by the ghastly screams of the dying women. The men are awarded the right to valiant speech while the metaphorical lack of voice which the women endure in their lives is reemphasized in a literal sense in their deaths. The physical location of the women and men is crucial; the dying wails of the women come from within the earth, while the men fight above on the ground. The nation in many cultures is referred to as the 'motherland'; it becomes a feminine entity that needs protection from invaders. The nation, therefore, is the metaphorical mother while the women are the literal ones. Sahni ends the episode with the women being swallowed up by the earth; they must sink into the soil of the motherland, in order to reap the harvest of purity and honour. The well becomes a symbolic womb of the earth that brings death instead of life. Ritu Menon, in her essay "Do Women Have a Country?" talks about the role of women "as biological reproducers of religious and ethnic groups" (Menon, 2002: 57). Menon refers to Nira Yuval-Davis and Floya Anthias and elaborates how they

\footnotetext{
${ }^{3}$ The Sikh slogan of victory.

4 'Allah-o-Akbar' is the Islamic Arabic phrase for 'God is Greatest'

${ }^{5}$ The Sikh Punjabi phrase, 'Sat Sri Akal', utilized as a battle cry in the novel is generally used as a form of greeting, meaning 'God is the eternal truth'.
} 
identify three other ways in which women's relationship to state and ethnicity can be seen as different from men's: as reproducers of the boundaries of ethnic or national groups, as participating in the ideological reproduction of the community, and as signifiers of ethnic national difference. (Menon, 2002: 57).

These three identifiers, which during a time of crisis are deployed with stark affirmation, are nonetheless operative in normal times as well; 'normal' precisely because these identifiers are at work through what Althusser has defined as the Ideological State Apparatus. Going back to Agamben, the identity of the woman-zoë is sketched out and highlighted through the demands of the bios. The needs of the sub-human picayune are irrelevant and her job is strictly transcribed in pertaining to the needs and orders of the bios. Zoë is nameless and voiceless, and the times when she is permitted to speak she simply echoes and mimics the voices of the bios.

Ninety Sikh women committed suicide during the Rawalpindi riots of March 1947. They did so not just out of the fear of abduction and sexual assault but more so to protect their country's and religion's honour. Feminist sociologist Urvashi Butalia in her book The Other Side of Silence writes about Basant Kaur, who was in her seventies when Butalia met her. She was a survivor of the horrific incident and Butalia includes her testimony of the same. Kaur narrates:

Many girls were killed. Then Mata Lajjawanti, she had a well near her house, in a sort of garden. Then all of us jumped into that... I also went in, I took my two children, and then we jumped in... the well filled up, and we could not drown...the children survived. Later, Nehru went to see the well, and the English then closed it up, the well that was full of bodies. (Butalia, 1998: 200)

It is significant to note that Basant Kaur was not a survivor because she refused to jump. She was not driven by the desire to seek an alternative solution for her protection; she survived because the well was already too full with dead bodies to drown her. Butalia later interviews Kaur's son, Bir Bahadur Singh, who was a witness to the incident. In his recollections he describes the deaths as a heroic act of the righteous Sikh community; he claims that if "those who jumped into the well had not taken their own lives, the ones who were left alive would not have been alive today" (Butalia, 1998: 210). Singh finds it crucial to point out that the women who escaped death were only able to do so because others took their place. Both testimonies also give rise to certain important questions: Were there any women who refused to kill themselves? What happened to those who resisted? Were they made to jump by their fathers and husbands? Or were they left alone, never to be spoken about or heard of again due to the disgrace they had brought upon their 
community in their selfish act of self preservation? Basant Kaur does not bear the shame of escaping martyrdom, since she did not try to deny death. Similar to her attempt at suicide driven by a sense of religious duty, her survival too was not of her own doing. She survived not because she wanted to but because of the circumstances. Throughout the interview, Kaur never chooses to call herself fortunate; she accepts her fate to live, which, yet again, does not differ from her silent acceptance of death. On returning to Singh's statement, one notices an insistence on the necessity of the suicides. This cannot conceal, however, the uncomfortable question of whether there was ever an alternative option that did not include rape, mutilation and murder by the religious Other. Basant Kaur survived - what if the other women did too? Would they have fallen prey to the wrath of the attackers? Singh's morbid comment, therefore, mirrors succinctly the position of women during the time of the communal violence.

For concluding remarks, I turn to Gloria Anzaldúa, one of the prominent writers of Chicana feminism and cultural theory, who refers to the Mexican-American border as "una herida abierta $^{6}$ where the Third World grates against the first and bleeds" (Anzaldúa, 1987: 25). If one attempts to read this statement in the context of South Asia, one can say that the Third World Indian Subcontinent, in its struggle for independence, cracks to give rise to new borders that open like dreary wells of death swallowing the woman for reproduction and reaffirmation of communal boundaries through their 'sacrificed' bodies.

\section{WORKS CITED}

Agamben, Giorgio (1998). Homo Sacer: Sovereign Power and Bare Life (trans. Daniel HellerRoazen), Stanford, California: Stanford University Press.

Althusser, Louis (1971). Lenin and Philosophy, and Other Essays (trans. Ben Brewster), Delhi: Aakar Books, 2006.

AnZAldúA, Gloria (1987). Borderlands/La Frontera: The New Mestiza, San Francisco: Aunt Lute Books, 1999.

\footnotetext{
6 'Una herida abierta' is Spanish for 'an open wound'. 
Butalia, UrVashi (1998). The Other Side of Silence: Voices from the Partition of India, Navi Mumbai: Penguin Books India.

ChatterJee, Partha (1989). "Colonialism, Nationalism, and Colonialized Women: The Contest in India", American Ethnologist, Vol. $16 \mathrm{~N}^{\circ}$ 4, November: 622-633. $<$ http://www.jstor.org/stable/645113?origin=JSTOR-pdf $>$ accessed 4 March 2014. DOI: 10.1525/ae.1989.16.4.02a00020

Foucault, Michel (2003). Society Must be defended: Lectures at the Collège de France, 197576 (trans. David Macey), Mauro Bertani \& Alessandro Fontana (eds), New York: Picador.

MENOn, Ritu (2002). "Do women have a country?”, In: Rada Iveković and Julie Mostov (eds). From Gender to Nation, New Delhi: Kali for Women, 2004: 43-62.

Pandey, Gyanendra (2001). Remembering Partition: Violence, Nationalism and History in India, Cambridge: Cambridge University Press.

SAHNI, BHISHAM (2001) Tamas, Navi Mumbai: Penguin Books India.

ARUnima Dey is a PhD student in the Department of English at the University of Salamanca 